\title{
Case Studies in Clinical Biochemistry
}

\author{
Murphy MJ, Srivastava R and Gaw A. SA Press, June 1, 2012, Paperback, 132 pp, \\ Kindle e-book, ISBN 978-09563242-4-5
}

\section{Praveen Sharma}

Published online: 14 October 2012

(C) Association of Clinical Biochemists of India 2012

The authors of the best-selling "Clinical Biochemistry: An Illustrated Colour Text" from Elsevier have now produced a companion volume. Clinical Biochemistry is about patients- how we investigate their signs and symptoms, how we diagnose their illnesses and how we treat them. In this new book, the authors from the UK present a series of over 50 clinical cases, all based on real patients, and invite the reader to answer key questions using their knowledge and experience of each topic. Topics covered include Fluids and Electrolytes, Acid-Base Balance, Renal and Liver Function, Calcium and Bone Disease, Proteins and Enzymes, Diabetes, Endocrinology, Lipids, Toxicology and Paediatrics. The book also contains a very useful further reading section and links to relevant websites.

Each case study consists of a short clinical history accompanied by key clinical findings and laboratory results, and a series of questions. The authors' detailed answers and explanations to these questions can found by simply turning the page. The case studies and their questions are designed to address key teaching points in Clinical Biochemistry and to do so in the context of real clinical experience. As such it is an ideal revision aid for those studying Medicine, Nursing and Biomedical Sciences and for those preparing for postgraduate membership examinations.

As an important added extra, a unique facebook page has been created to allow readers to access additional educational

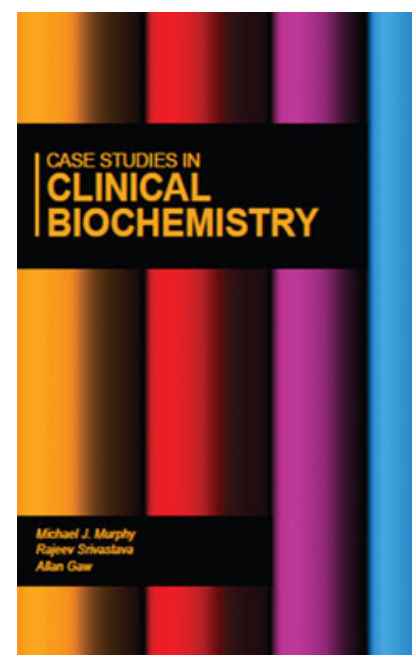

material not found in the book, and to interact directly with the authors, Michael Murphy, Rajeev Srivastava and Allan Gaw. You may find them on www.facebook.com/ClinicalBiochemistry and you can follow them on twitter @SAPress42.

The 132 page book is available to purchase on amazon. A kindle version is also available for download at $\$ 7.43$ from www.amazon.com.

P. Sharma $(\bowtie)$

Department of Biochemistry, All India Institute of Medical

Sciences, Jodhpur, India

e-mail: praveensharma55@gmail.com 